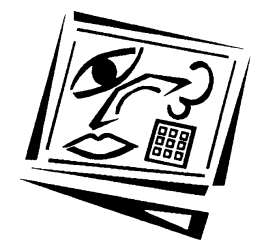

\title{
The use of a visual learning design representation to support the design process of teaching in higher education
}

\author{
Shirley Agostinho \\ University of Wollongong
}

\begin{abstract}
Over the last decade there has been considerable research and development work exploring how university teachers can document their teaching practice in such a way as to enable the sharing of ideas. The premise of this research work, referred to in the literature as learning designs, is if pedagogical practice can be documented in some readily understandable form, it can then be easily shared and thus there is the potential for greater uptake of innovative teaching practice. This paper presents findings from a research project that examined how educational designers and teaching academics used a visual learning design representation to document their teaching practice and how this representation supported their design process. Six educational designers, three university teachers, and two PhD students (whose doctorates were focused on learning design) were interviewed and the main finding was that the visual representation served as an aid to design because it provided a summary of pedagogical practice that could be used to effectively communicate and share ideas, and also enable reflection. The paper concludes by suggesting future research directions.
\end{abstract}

\section{Introduction}

The higher education sector has experienced a shift towards offering students more flexible learning opportunities through the use of information and communication technology (ICT). The use of ICT in university course offerings is becoming mainstream and with this, teachers are faced with the ongoing challenge of designing pedagogically sound learning experiences for their students that effectively integrate ICT. This context has been the catalyst for research and development work focused on how academics can be supported to design learning environments that effectively integrate ICT. A key argument in this research work is that the existing ways of representing and disseminating pedagogical practice and guidance needs improvement as many current forms of guidance may not be easily accessible. For example, Goodyear (2005) and Sharpe, Beethham and Ravenscroft (2004) have argued that conventional channels of dissemination, which are mostly text-based genres such as principles explained in books and case studies and research findings reported in journal and conference publications, do not go far enough in terms of explicating how research-based evidence of pedagogical theory can be translated into pedagogical practice. They have called for a representation of design knowledge that bridges this gap, that is, a representation that could be more accessible and usable by academics.

Another aspect of this discourse is the call for standardisation in documenting teaching practice in higher education - similar to that of the 'lesson plan' construct 
adopted by teachers in the primary and secondary school contexts. It has been argued that a design language and/or notation system for educational design is needed, similar to that found in other disciplines such as music and dance, to provide a common language that will allow better communication of ideas, and in turn could serve as a stimulus to improve the quality of teaching and learning (Gibbons \& Brewer, 2005; Seo \& Gibbons, 2003; and Waters \& Gibbons, 2004).

Over the last ten years, the concept of learning designs has evolved as a strategy towards a common language to serve as an accessible and usable form of guidance for university teachers (Lockyer, Bennett, Agostinho \& Harper, 2009). Learning design can be considered as either a process of designing learning experiences (Conole, 2009) or a documented outcome of the design process (Agostinho, 2009). The definition for learning design adopted in this paper is a representation of teaching and learning practice documented in some notational form.

A learning design could be used as a way to share and model expert practice. For example, a teacher could refer to another teacher's learning design as an example or case of expert practice to gain ideas on how to design a 'high quality' learning environment. Teachers could also use a learning design representation to document their own teaching practice for the purpose of describing, discussing and reflecting on their educational design.

What constitutes a learning design and how it ought to be described is a current research focus (Neumann, Oberhuemer \& Derntl, 2009). Large scale research and development projects have devised different learning design representations, for example:

- IMS Learning Design Best Practice and Implementation Guide Version 1.0 Final Specification, 2003, http:/ / www.imsglobal.org/;

- LAMS http://www.lamsinternational.com/;

- Learning Designs project http://www.learningdesigns.uow.edu.au, and

- The Pedagogical Patterns project http:/ / www.pedagogicalpatterns.org/

There have also been research projects that have explored the challenges of describing practice (Falconer, Finlay \& Fincher, 2011). What is needed to contribute to this research and development work is more empirical studies that examine how particular learning design representations are being used by teachers and how they can affect the design process. This paper presents findings from a research project that examined how academics used a visual learning design representation to document their teaching practice and how such a representation influenced their design process.

\section{Learning design representations}

Several learning design representations have emerged over the last decade and those featured in recent research work include:

- $E^{2} M L$ : Educational Environment Modeling Language (E²ML) (Botturi, 2006) represents a learning design as a structured set of activities aimed towards achieving a set of defined learning outcomes. It was developed to enhance communication within elearning project teams. 
- IMS LD: IMS Learning Design (IMS Learning Design Best Practice and Implementation Guide Version 1.0 Final Specification, 2003) represents a learning design as a sequence of activities described in the form of acts in a play (referred to as a "unit of learning"). It is documented in a computer readable format (an XML file) and its purpose is to offer technical interoperability.

- LAMS: Learning Activity Management System (LAMS)

(http:/ / www.lamsinternational.com/) is a software application that allows a teacher to both design and implement online learning activities using a visual authoring environment. The learning design is visually represented in a flow-chat as a sequence of activities, which are represented in the form of the online tools used to run each activity.

- LDVS: The Learning Design Visual Sequence (Agostinho, Harper, Oliver, Hedberg \& Wills, 2008) documents a learning design in a visual way by illustrating the chronology of tasks, resources and supports using symbols for each of the three learning design elements (squares/rectangles for tasks, triangles for resources and circles for supports). A time period for the learning design and intended learning outcomes are also included.

- LDLite: LDLite (Falconer, Beetham, Oliver, Lockyer \& Littlejohn, 2007; Oliver \& Littlejohn, 2006) documents a learning design in a tabular form and is based on five key elements of IMS LD: tutor roles, student roles, content resources, service resources and assessment/feedback. It is used to help teachers design blended activities, that is, integrate face-to-face and online activities.

- Patterns: A pattern can be considered as an overall "rule of thumb" (McAndrew \& Goodyear, 2007). The learning design is represented as a series of text-based paragraphs containing information such as: context for the pattern, description of the problem, solution, example, and link(s) to other patterns. The way patterns can link to other patterns to form sets is referred to as a pattern language. The purpose of a pattern language "is not to present an exact algorithm that generates a design specification in accordance with a given instructional environment, but to explain and teach about good design" (Voigt, 2010, p. 107). Thus patterns can offer guidance and the interconnectedness of patterns via a pattern language enable guidance to be offered at various levels of specificity.

Each of these learning design representations document a learning design in a different way and it can serve different purposes. For example, patterns aim to disseminate design knowledge (Voigt, 2010) whereas the purpose of $E^{2} \mathrm{ML}$ and IMSLD is to document a contextualised learning design, thus they provide specificity and logistical detail of a learning design.

Whilst there has been considerable research work in the development of these representations there are calls for more empirical studies that examine how teachers and/or educational designers are actually using these learning design representations. For example, Frizell and Hübscher (2009) and Garzotto and Retalis (2009) have argued for more research on design patterns to gain a better insight on user experiences and how design patterns can affect the design process. Some work that has reported on teacher experiences with various learning design representations includes: 
- Hazelwood, Oddie and Barrett-Baxendale (2009) reported practitioner use about creating IMS-LD units of learning and how IMS-LD units of learning work with learners.

- Frizell and Hübscher (2009) and Garzotto and Retalis (2009) explain how design patterns can and are being used in education particularly for e-elearning.

- Bennett, Agostinho and Lockyer (2005) reported on a case study about teachers reusing learning designs from the Learning Designs project.

- Falconer and Littlejohn (2006) reported on a UK JISC funded project - MOD4L where teacher participants reviewed three learning design representations (LDLite, LDVS, and Patterns) and provided their opinions about the perceived usefulness of these representations.

- Neumann, Oberhuemer and Derntl (2009) have presented a position paper on how graphical representations may support the use and uptake of IMS-LD.

This paper presents an empirical study on how the LDVS has been used by eleven participants in the university context. Some historical background and detailed description of the LDVS is provided below followed by the methodology of the study.

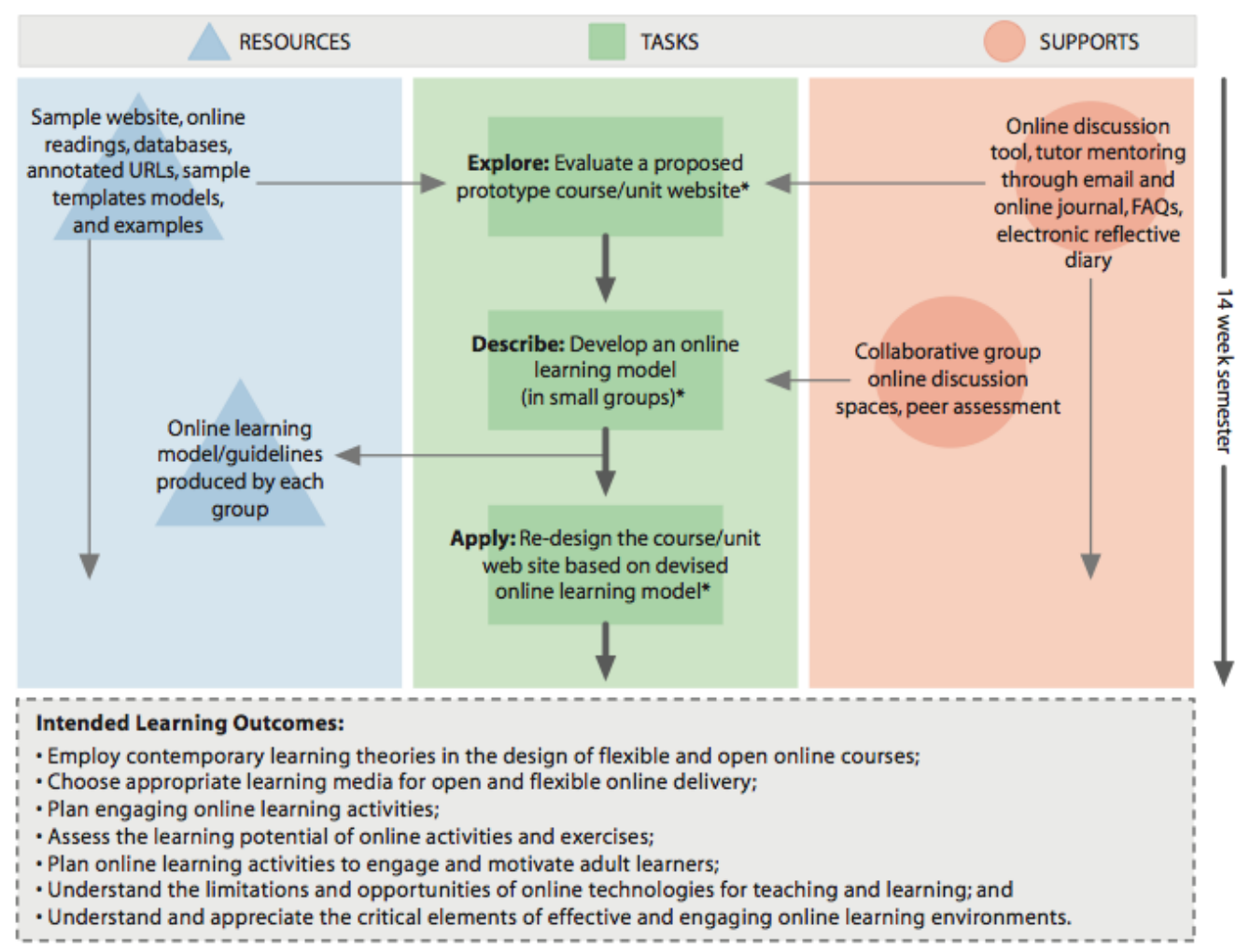

Figure 1: Example of a LDVS taken from the Learning Designs project (Herrington \& Oliver, 2002). See

http:/ / www.learningdesigns.uow.edu.au/exemplars/info/LD20/more/03Context.html

The LDVS was developed from an Australian nationally funded project that focused on producing innovative reusable learning designs (Agostinho et al. 2008). The LDVS illustrates tasks students are required to undertake, content resources provided to 
assist students to complete the tasks and supports provided by the teacher. On the project web site (http://www.learningdesigns.uow.edu.au/), the LDVS is accompanied with detailed textual information that explains the tasks, resources and supports in detail and guidance is provided on how the learning design can be implemented. Figure 1 shows an example of a LDVS.

Figure 1 represents a learning design implemented in a course focused on online learning and teaching. The course consists of three assessable tasks (indicated with an asterisk, ${ }^{*}$ ) that students are required to complete within a 14 -week time frame. The overall pedagogical design of this learning design is problem based as students need to firstly examine an online learning example (first task rectangle), which is provided as resources (first resource triangle) to identify key characteristics, then they need to describe the key characteristics by articulating them in the form on an online learning model (first task rectangle and a documented artefact - second resource triangle) and thirdly they then apply their devised model to produce their own online learning environment (third task rectangle). The teacher supports students during this process by providing specific feedback via email, providing online discussion opportunities for students (first support circle) and encouraging them to work together (second support circle). Horizontal arrows are used to illustrate the connection between tasks and resources and tasks and supports. Vertical arrows are used to link the tasks and also indicate when the same resource or support is provided for subsequent tasks (see first resource triangle and first support circle).

\section{Methodology}

Data was collected through semi-structured, in depth interviews with 11 participants from four Australian universities: The University of Wollongong (8), The University of Sydney (1), Queensland University of Technology (1) and University of Canberra (1). Six participants were learning/educational designers working in central support units within their university institution, three were teaching academics within an education faculty, and two were doctoral students in an education faculty that were involved in individual projects that used the LDVS.

Participants were purposefully selected. The researcher (from her involvement in the development of the LDVS) initially identified eight participants who were using the LDVS in their work context. They were contacted via email to invite participation in this study and all agreed to participate. The participants were asked if they knew of other colleagues who were using the LDVS or accessing the project web site and a further three participants were recruited.

One semi-structured interview was conducted with each participant during 2006, either face to face or via telephone. The interview duration ranged from 40 to 90 minutes. Each interview was recorded and transcribed and the transcription was sent to each participant for review. Five participants also provided examples of the LDVS diagrams they had developed. The interview was structured into three sections and the following key questions were asked:

1. Participant profile: What is your work role? How did you know about the Learning Design project?

2. Context of use: Why have you accessed the Learning Designs project web site? How have you used the LDVS? 
3. Assessment of usefulness: What do you think are the main strengths and weaknesses of the LDVS? Do you think the LDVS provides a useful summary of a learning design? What suggestions would you recommend to improve the LDVS?

The interviews were initially reviewed using a data analysis technique referred to as "skimming the cream" (Smith, 1978) where the researcher brainstormed the dominant themes emerging from the interviews. An in-depth analysis was then undertaken where the data was analysed according to the overall structure of the interviews. Each idea in the interview transcription (be it a sentence or paragraph) was coded. Themes were then categorised in order of dominance. The findings from the more in-depth analysis were then triangulated with the initial data analysis to determine if the preliminary findings corroborated with the more in-depth analysis. The preliminary findings were overall consistent with the findings from the in-depth analysis. The results are presented below according to the structure of the interview. Pseudonyms have been used to maintain anonymity of participants.

\section{Results}

\section{Participant profile}

Participants knew about the Learning Designs project by either direct involvement in the project (5), being made aware of the project web site by colleagues (5), or hearing about the project at a conference (1). Table 1 provides a summary of each participant's profile.

Table 1: Participant profile

\begin{tabular}{|c|c|c|c|}
\hline $\begin{array}{l}\text { Participant } \\
\text { (pseudonym) }\end{array}$ & Work role & University & $\begin{array}{c}\text { How they knew about the } \\
\text { Learning Design Project }\end{array}$ \\
\hline Catherine & $\begin{array}{l}\text { Learning/Educational } \\
\text { designer }\end{array}$ & $\begin{array}{l}\text { University of } \\
\text { Wollongong }\end{array}$ & Recommended by colleagues \\
\hline Jennifer & Teaching academic & $\begin{array}{l}\text { University of } \\
\text { Wollongong }\end{array}$ & $\begin{array}{l}\text { Involved in Learning Designs } \\
\text { project }\end{array}$ \\
\hline Kate & $\begin{array}{l}\text { Learning/Educational } \\
\text { designer }\end{array}$ & University of Sydney & $\begin{array}{l}\text { Involved in Learning Designs } \\
\text { project }\end{array}$ \\
\hline Linda & Teaching academic & $\begin{array}{l}\text { University of } \\
\text { Wollongong }\end{array}$ & $\begin{array}{l}\text { Involved in Learning Designs } \\
\text { project }\end{array}$ \\
\hline Lorraine & Teaching academic & $\begin{array}{l}\text { University of } \\
\text { Wollongong }\end{array}$ & $\begin{array}{l}\text { Involved in Learning Designs } \\
\text { project }\end{array}$ \\
\hline Narrell & $\begin{array}{l}\text { Education doctoral } \\
\text { student }\end{array}$ & $\begin{array}{l}\text { University of } \\
\text { Wollongong }\end{array}$ & Recommended by supervisors \\
\hline Paul & $\begin{array}{l}\text { Learning/Educational } \\
\text { designer }\end{array}$ & University of Canberra & Heard about it at a conference \\
\hline Rachel & $\begin{array}{l}\text { Learning/Educational } \\
\text { designer }\end{array}$ & $\begin{array}{l}\text { Queensland University } \\
\text { of Technology }\end{array}$ & Recommended by colleagues \\
\hline Samantha & $\begin{array}{l}\text { Learning/Educational } \\
\text { designer }\end{array}$ & $\begin{array}{l}\text { University of } \\
\text { Wollongong }\end{array}$ & $\begin{array}{l}\text { Involved in Learning Designs } \\
\text { project }\end{array}$ \\
\hline Stephanie & $\begin{array}{l}\text { Learning/Educational } \\
\text { designer }\end{array}$ & $\begin{array}{l}\text { University of } \\
\text { Wollongong }\end{array}$ & Recommended by colleagues \\
\hline Warren & $\begin{array}{l}\text { Education doctoral } \\
\text { student }\end{array}$ & $\begin{array}{l}\text { University of } \\
\text { Wollongong }\end{array}$ & Recommended by supervisors \\
\hline
\end{tabular}

When participants were asked why they accessed the Learning Design project web site, all responded that the web site provided a source of teaching and learning examples documented in a useful and accessible way. An indicative comment was: 
The thing that interests me most about it is the idea that an academic without great expertise in a particular teaching and learning strategy could come to the website, find something that suited them and their class and be able to adapt that from an exemplar that's already there. (Linda)

\section{Context of use}

Eight of the 11 participants had produced their own LDVS within their work context. Upon discussing with the participants how closely they had applied the LDVS notation system and reviewing supplied examples of LDVS diagrams, it was found that whilst all eight participants had adopted the general principles of the notation system (as illustrated in Figure 1), five had created their own diagrammatic variations. Of these five, two participants made minor modifications and three participants made significant modifications to the LDVS notation system.

Minor modifications (made by Stephanie and Samantha) involved not including learning outcomes and a time line on their diagrams. Stephanie also used a different symbol to represent resources (clouds instead of triangles) so that the text would fit inside the symbol. Major modifications to the LDVS notation system (made by Catherine, Lorraine and Rachel) involved the following:

- Catherine produced a LDVS that illustrated the tasks, resources and supports in a horizontal format rather than in a vertical sequence. Use of arrows was excluded and the time line was provided at the bottom on the diagram. (See Figure 2.)

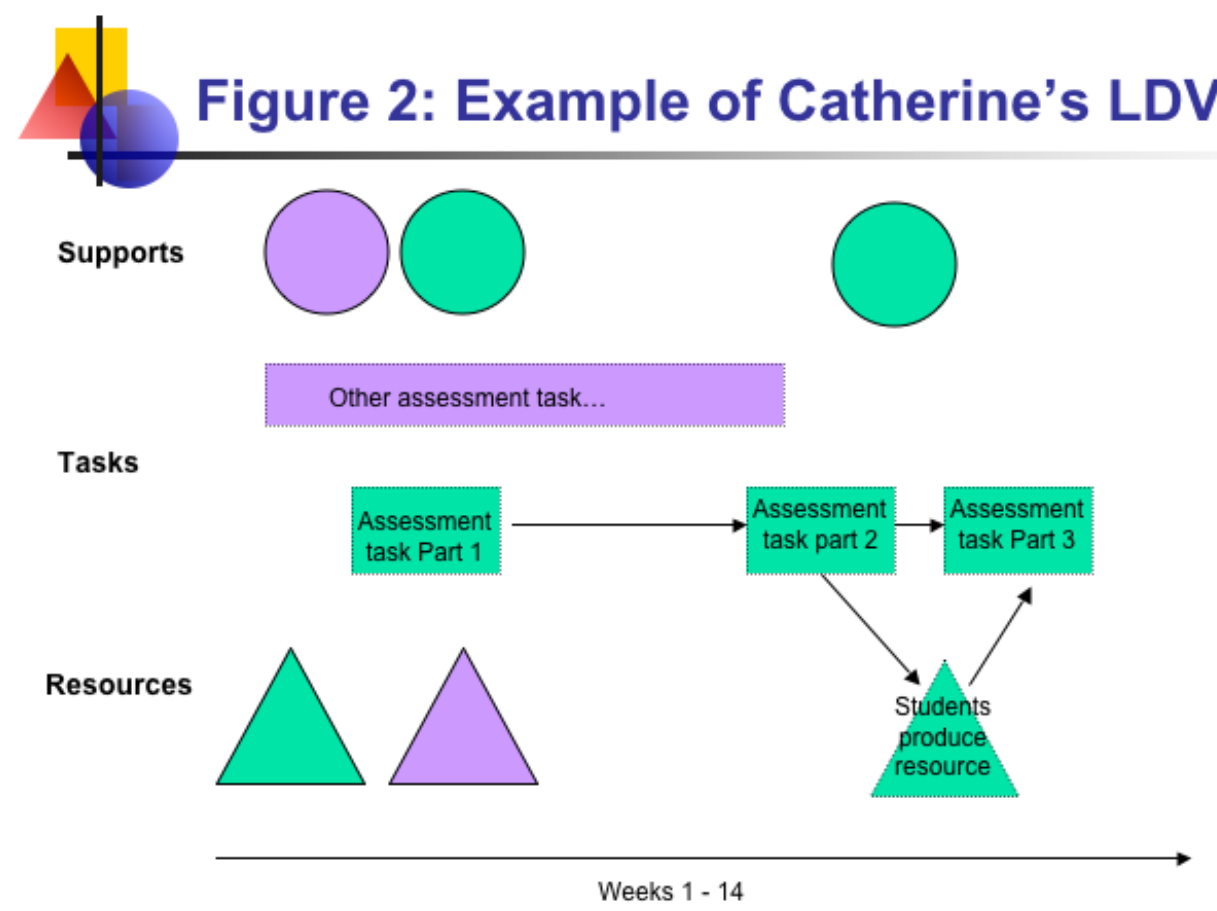

Figure 2: Example of Catherine's LDVS 
- Lorraine used lines instead of arrows to link the resources and supports symbols to the respective task rectangles. Multiple supports for one task were represented as clustered circles (that is, circles that overlapped each other). A time line and learning outcomes were excluded. (See Figure 3.)
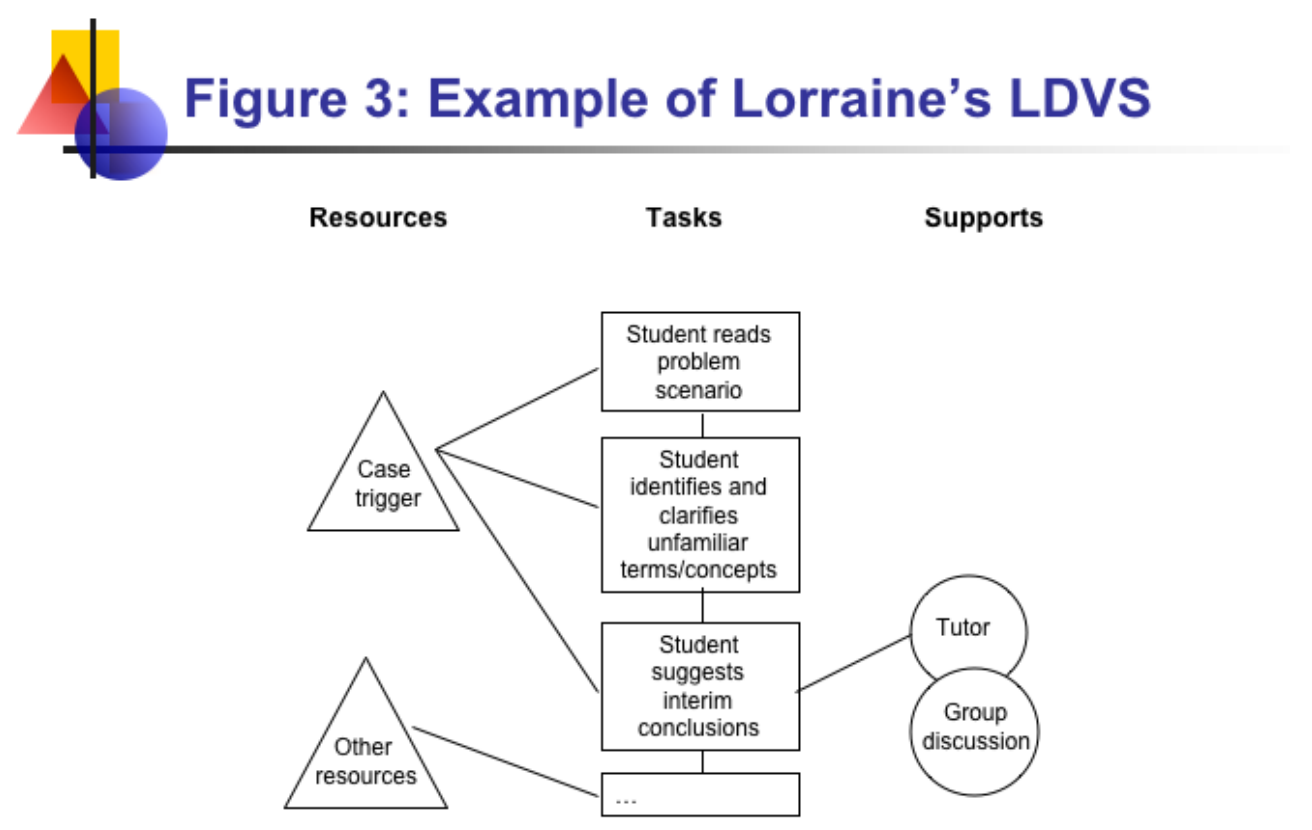

Figure 3: Example of Lorraine's LDVS

- Rachel included an additional support column to the LDVS to represent the support provided to tutors when implementing her learning design. (See Figure 4.)

Three of the 11 participants (Jennifer, Kate and Paul) had not specifically drawn their own LDVS. Instead, Jennifer and Paul had applied the overall learning design components of tasks, resources, and supports (Oliver \& Herrington, 2001) when designing their teaching. Jennifer explained that she applied the model in a textual tabular form when designing tasks in her subjects. She explained that she would produce a table with five columns: the first column provided the rationale for the task, the second column described the task as it would be presented to students, the third and fourth columns explained the resources to be provided to students - ones specifically related to the task and ones that are more general, and the last column detailed how she, the teacher, would support her students. Paul said that the tasks, resources, and supports learning design model helped him to focus on the tasks rather than on the content (resources) when designing a course/subject. In his role as an educational designer he demonstrates the Learning Design project web site to staff as a useful resource.

Kate explained she often referred to the Learning Designs project web site for ideas and suggested it as a useful resource to colleagues. Whilst she thought that the overall Learning design models of tasks, resources and supports was a "nice way of thinking through the different things that you need in a Learning Design", she had not 


\section{Figure 4: Example of Rachel's LSVS}

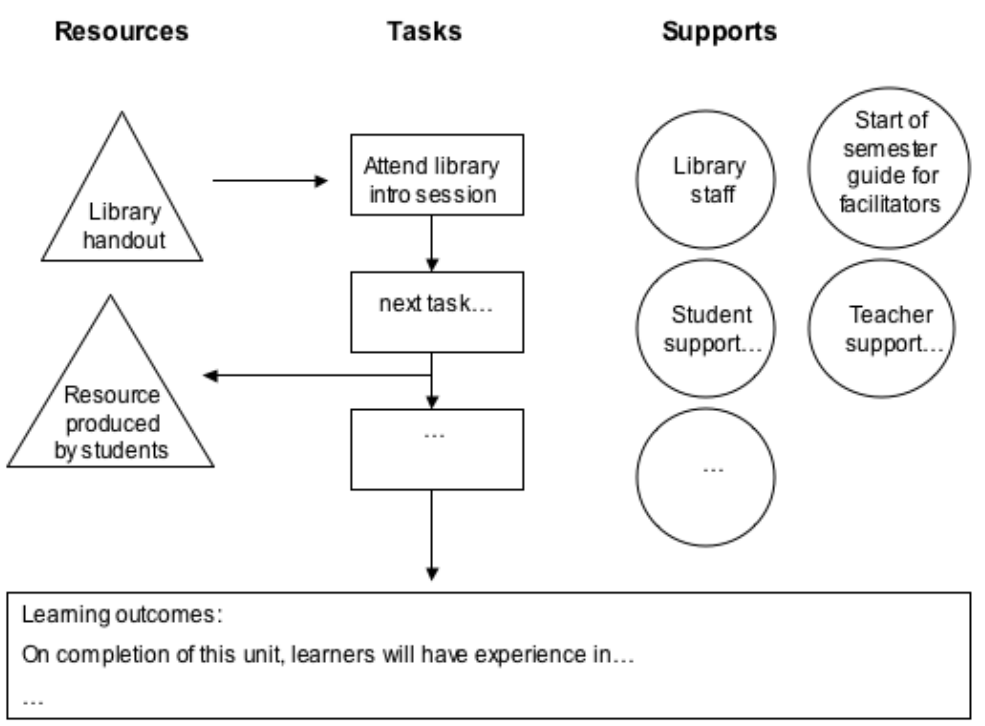

Figure 4: Example of Rachel's LSVS

specifically applied these concepts. Instead she used her own diagram to discuss ideas with clients. Upon review of her diagram, it was similar to the LDVS in that the focus was on the student tasks and their sequence, but resources and supports were not explicitly illustrated.

From the ten participants who had either created their own LDVS or applied the overall learning design model of tasks, resources and supports, three themes surfaced as to the purpose for using the LDVS:

- A documentation tool to summarise and communicate a learning design implemented in a course/ subject.

- A tool used during the design process of a course/ subject/ activity to communicate and discuss pedagogical ideas.

- An analysis tool to reflect on a learning design implementation within a course/ subject.

Each of these three themes is further explained below.

\section{Documentation tool}

Of the eight participants who had created their own LDVS, their purpose for using the LDVS notation system was as a documentation tool for the following reasons:

- To facilitate communication amongst colleagues. For example, Linda explained: "It became a way for my colleague... and I to jointly work on something to really 
understand a design. So we used that as a language and a means to express what we were coming up with.... We just put in a paper to [journal name] and we used that formalism to represent our design".

- To clearly articulate a learning design in an academic publication. For example, Stephanie explained: "I did a project with a client... and we wrote the outcome up as a paper and I suggested that a diagram is always good for a paper".

- To facilitate dissemination and uptake of learning designs. For example, Stephanie thought the way the LDVS presents a summary of a learning design was particularly useful for dissemination: "generally what I find in a dissemination environment is it's better to give less and let people ask questions." Linda had used the LDVS to help other academics apply a new teaching strategy: "So taking problem based learning, looking at what models there were of problem based learning and... discussing around the graphical model, and that's I think easy to do because it's very accessible compared to a lot of text".

- To document the evolution of a learning design by creating iterative versions of LDVS, or to show the contrast of learning designs for comparison. For example, Lorraine noted: "I've used it for describing the [name of project] and showing how that has translated over time in terms of the actual design of the educational program. So I find that for me it's a good way of communicating to someone what a design is".

- For post-project documentation. Samantha's intention of a future project was to create an online repository of learning designs focused on a particular pedagogical strategy and thus thought the LDVS was a suitable way to document these learning designs.

\section{Design tool}

As mentioned previously, two participants, Jennifer and Paul, used the learning design model of tasks, resources, and supports as a personal design tool when planning tasks in their subjects/ courses. Of the eight who had created their own LDVS, four participants (Lorraine, Stephanie, Rachel and Warren) used the LDVS as a design tool to either help them think through a learning design or use it to facilitate dialogue and communication between themselves and their clients. For example, Stephanie and Rachel, who were learning/educational designers, used their LDVSs to focus their discussions with clients. Rachel explained that she used the LDVS as a "talking point" with her client:

To give them an overall picture of what we're talking about. I think with each client I usually use a visual representation... and I've found that so far it has been useful... it sort of teases apart our conversation, particularly to get the client to start thinking about what the learners are actually doing.

Stephanie used her LDVS diagrams in a similar manner as to Rachel:

You actually sit down at the first meeting and just start with this diagram and say, hello I'm using this diagram here because I need to understand your subject and your teaching and your needs, and any issues that you have. So if you don't mind I'd just like to start going through all these things. 
Warren found the LDVS a useful design tool when working on a project where he had to design web-based templates: "I was employed to... help design a few templates... and it worked ... very, very well."

\section{Analysis and reflection tool}

Three participants used the LDVS as an analysis or reflection tool to help them check their own understanding of a learning design. For example, Lorraine noted: "It's helpful for me to understand learning environments particularly that I've constructed ... it also helps me check what I understand to be the design because I can look at the elements and see if anything is missing".

Stephanie explained it was not a trivial task to produce the LDVS diagram: "it takes a lot of your brain space to really work through it". Catherine thought the LDVS was particularly helpful as an analysis and reflection tool that can be adjusted or modified relatively easily to answer 'what if' type questions during subject re-design.

Table 2 presents a summary of the ten participants that had created their own LDVS or applied the overall learning design model of tasks, resources and supports, in terms of its purpose for use, and how they complied with the LDVS notation system.

Table 2: Summary of 10 participants and how they used the LDVS

\begin{tabular}{|c|c|c|c|}
\hline Name & $\begin{array}{l}\text { Created own } \\
\text { LDVS? }\end{array}$ & Variations made to the LDVS notation system & Purpose for use \\
\hline Catherine & Yes & $\begin{array}{l}\text { - Horizontal rather than vertical sequence } \\
\text { - Arrows excluded } \\
\text { - Time line provided at bottom of diagram }\end{array}$ & $\begin{array}{l}\text { Analysis and } \\
\text { reflection tool }\end{array}$ \\
\hline Jennifer & No & $\begin{array}{l}\text { Used the learning design construct of tasks, } \\
\text { resources and supports in a table with five columns: } \\
\text { - Column 1: Task rationale } \\
\text { - Column 2: Task description } \\
\text { - Column 3: Resources specific to task } \\
\text { - Column 4: General resources provided } \\
\text { - Column 5: Support provided by teacher }\end{array}$ & Design tool \\
\hline Linda & Yes & Complied with LDVS notation system & Documentation tool \\
\hline Lorraine & Yes & $\begin{array}{l}\text { - Excluded time line and learning outcomes } \\
\text { - Used lines instead of arrows to link resources } \\
\text { and supports to respective tasks } \\
\text { - Multiple supports for one task presented as } \\
\text { overlapping circles }\end{array}$ & $\begin{array}{l}\text { Documentation, } \\
\text { analysis and } \\
\text { reflection tool }\end{array}$ \\
\hline Narrell & Yes & Complied with LDVS notation system & Documentation tool \\
\hline Paul & No & $\begin{array}{l}\text { Used the learning design construct of tasks, } \\
\text { resources and supports to focus on tasks rather than } \\
\text { content when designing a course/ subject }\end{array}$ & Design tool \\
\hline Rachel & Yes & $\begin{array}{l}\text { Added another support column on right of LDVS } \\
\text { to represent support required by tutors during } \\
\text { implementation. }\end{array}$ & $\begin{array}{l}\text { Documentation and } \\
\text { design tool }\end{array}$ \\
\hline Samantha & Yes & Excluded time line and learning outcomes & Documentation tool \\
\hline Stephanie & Yes & $\begin{array}{l}\text { - Excluded time line and learning outcomes } \\
\text { - Used a 'cloud' symbol to represent resources } \\
\text { (instead of triangles) }\end{array}$ & $\begin{array}{l}\text { Documentation, } \\
\text { design, analysis } \\
\text { and reflection tool }\end{array}$ \\
\hline Warren & Yes & Complied with LDVS notation system & $\begin{array}{l}\text { Documentation and } \\
\text { design tool }\end{array}$ \\
\hline
\end{tabular}


Three participants, Catherine, Samantha, and Stephanie had used the LDVS in conjunction with other documentation tools to help them better understand, interpret or compare a learning design. For example, in her client meetings, Stephanie accompanied a LDVS she had created with the subject/course outline. Samantha mentioned that she had produced a comparison matrix of similar learning designs to help her compare and contrast several learning designs. Catherine thought that the use of multiple documentation tools added a dimension of richness thus aiding the comprehension of a learning design.

\section{Assessment of usefulness}

Overall, all participants (regardless of whether they created their own LDVS or not) thought that the LDVS was useful to document and communicate teaching and learning ideas with others. The visual feature of the LDVS was viewed as its main strength. Other strengths in order of dominance were its structure, simplicity and adaptability. These are discussed as follows.

Visual feature: Ten of the 11 participants thought the visual feature of the LDVS was its main strength. The graphical aspect assisted the understanding of a learning design as it provided an overall summary or snapshot. For example, Narrell commented, "you can show a complete... unit for work, in sort of one space." Several respondents said the LDVS took the mystery out of a learning design as it showed the key elements. For example, Linda noted that the LDVS "allows you to very quickly understand what the scope and sequence of the learning design is". Paul was the only participant that didn't comment on the visual feature. Instead he thought the strength of tasks, resources, and supports learning design model was that "it's a model that if you follow it, it's going to lead to a richer learning environment".

Structure: Four participants (Linda, Rachel, Samantha, and Stephanie) thought that how the LDVS illustrated the sequence or chronology of tasks helped them understand the mechanics of how to implement a learning design. Rachel, for example, commented that the LDVS allowed her to "see the whole process... it breaks it down into bite sized chunks so it's not so overwhelming". Linda explained that the LDVS can help illustrate to a teacher/designer how a particular pedagogical approach (e.g. problem based learning and authentic learning, etc.) can be operationalised.

Simplicity: Three participants (Jennifer, Lorraine and Warren) explicitly commented that the LDVS was simple to understand and use. Lorraine commented that it was a simple formalism that required little training for someone to understand and use it. She also noted that a LDVS is quick to review thus offers an element of efficiency: "I don't think that designers or teachers always necessarily have the time to read dense case studies of other people's work and then try to translate it into their own situation". Warren provided the following summation: "It's simple, it's clear, it's concise and it works".

Adaptability: Three respondents, Stephanie, Linda, and Rachel mentioned that the LDVS could be easily adapted to suit one's needs. Stephanie adapted the LDVS to suit the needs of clients. For example, for one client, instead of using the terms 'tasks' and 'supports' on her LDVS she used 'partnership tasks' and 'community engagement' respectively to better suit her client's learning design. Linda thought that the LDVS can provide teachers with guidance but it is "not rigid, it's not like a recipe". 
In terms of weaknesses of limitations of the LDVS, three issues surfaced: i) ambiguity of what is a 'resource' and 'support', ii) diagram can become complicated, and iii) there is little instruction on how it works. Each of these weaknesses is discussed in turn.

Ambiguity of 'resource' and 'support'

A limitation of the LDVS that six participants (Catherine, Kate, Linda, Lorraine, Narrell, and Stephanie) noted was the lack of clarity over what constituted a "resource" and a "support". Narrell said: "The only thing I struggled with a little bit was the differences between the resources and the supports". For example, a support was considered as something the teacher provides to help students. But if a teacher were to provide students with support through the provision of a template, or proforma to help students complete a task, it was not clear whether that remains a support or becomes a resource. Linda explained that this was the main weakness of the LDVS in terms of it serving as a notation system because "the whole point is that we all understand the basis of it. There shouldn't be ambiguity about it. So I think that's one thing that could be really clarified and some work needs to be done on it".

Diagram can become complicated

Four participants thought that the LDVS diagram could become complicated, especially, as Warren noted, if there are iterative tasks. Lorraine also raised this concern and noted that linear nature of the LDVS, which was deemed a strength, could be a potential weakness: "the linear nature may be an issue in that if you want to describe a non-linear sequence it could get messy". Catherine and Jan thought there was not enough room to include all the tasks, namely the non-assessable tasks in a LDVS. Catherine discussed this as an issue of granularity and suggested that if an assessable task was complex, it could be documented as multiple LDVS diagrams. Jennifer explained that was the reason she opted for using a table format instead: "there's not enough room there to have a complex task. You can only summarise it there, so that's why I then go to the tables".

\section{Little instruction on how it works}

Linda and Warren commented that the LDVS was not well known (thus not widely used) and there was little instruction on how a LDVS can be created. The eight participants who produced their own LDVS learned how to interpret and create a LDVS either through their involvement in the AUTC learning design project (3), examining the AUTC project web site and discussing the LDVS formalism with colleagues (3), or through self-study (2).

The following list summarises suggestions for improvement of the LDVS as a learning design representation:

- Remove the ambiguity between a 'resource' and 'support'. This could be achieved by publishing how the LDVS works, which would include providing a clear definition and examples of resources and supports.

- List the intended learning outcomes and a summary statement of the rationale for the tasks at the top of the diagram, to set the context of the learning design.

- Distinguish between critical and optional tasks, resources and supports.

- Add an additional support column to explain how a teacher can be supported when implementing the learning design. 


\section{Discussion}

The results from this study suggest that the LDVS can be a useful tool to support the design process. The visual feature of the LDVS was considered its biggest strength. The ability to illustrate a summary or snapshot of a learning design aided participants' ability to understand a learning design. The learning design components of tasks, resources, and supports, provided a useful framework for participants to focus on the key aspects of a learning design thus enabling them to check if anything was missing. Most found it a useful framework to help them think about a learning design. Overall, participants found the LDVS simple to use and understand and were able to adapt it to suit their work context.

The main limitation of this learning design representation was the ambiguity over the definition of a resource and support. This was considered an impediment of this learning design representation as a standard notation system. Similar findings about the visual strength of the LDVS and its limitation in terms of ambiguity over resources and supports have been reported in other studies (Falconer et al, 2007). The removal of ambiguity between a resource and support was the main suggestion for improvement offered by participants. Other limitations noted were that the diagram can become complicated and there was little published about how the LDVS works. Interestingly, apart from several suggestions for improvement, participants did not think there were any fundamental aspects missing from the LDVS notation system.

Given that some participants used the LDVS in conjunction with other documentation methods or tools and that the LDVS is one of several existing learning design representations, reinforces the idea that it may not be possible nor feasible to develop an all-encompassing, standardised notation system to document a learning design. Instead, there is a realisation that describing practice is a complex and challenging endeavour and having multiple forms of representing practice, referred to as mediating artefacts (Conole, 2009; Falconer et al, 2011) or mediating representations (Falconer, 2007) may be helpful for teachers to support their design thinking. The different representations may also enhance communication and understanding of pedagogical ideas amongst teachers (Falconer, 2007). A current area of research and development work is focused on exploring how the learning design concept can be manifested into online design support tools for use by university teachers, to help them with the design of their teaching. Examples of key projects include: the London Pedagogy Planner project, the Phoebe project, and an example of a new tool currently under development is Learning Design Support Environment (see Masterman \& Manton, 2011 for a detailed explanation).

Referring back to the LDVS representation, since the completion of this research project, there is further evidence that the LDVS is being used to document teaching practice. For example, Hoban (2009) presented a LDVS to explain a Slowmation learning design, McLaughlan and Kirkpatrick (2009) have documented their role-play learning design using the LDVS notation system, Cooner (2010) has depicted a technology-enhanced blended learning design as a LDVS, and Kearney (2011) has illustrated a digital storytelling learning design using an elaborated form of the LDVS. There are also several projects that have incorporated the LDVS as an aid to disseminate and communicate pedagogical ideas. For example, educational designers at the University of Wollongong are using the LDVS as a tool to document and facilitate discussion amongst a teaching team in the development of a university subject (see SlideShare presentation http://www.slideshare.net/wendyuow/math- 
symp-2010). Elliott, Boin, Irvin, Johnson \& Galea (2010) have used the LDVS to document innovative cases about teaching scientific inquiry skills (see example on project web site: http:/ / www.scientificinquiry.meu.unimelb.edu.au/identification/ cases.html).

This research study has given some insight into how teaching academics and educational designers can use mediating artefacts such as the LDVS to aid their design process, but its limitation was that participants reported their experience retrospectively. What would provide further insight is to observe teachers in the actual process of design to capture a richer understanding of how such support tools could be used. A recent study that tracked university teachers' use of learning designs (documented using the LDVS) to support their design thinking and process is Jones (2011, 2009). This doctoral study examined the design process of nine academic teachers who selected an existing learning design, adapted it and implemented it their own teaching context. Preliminary findings suggest that the use of documented learning designs can be a useful support for design.

Furthermore, there is little known about how university teachers engage in the broad activity of design (Goodyear, 2005). This is important to know so that we can better understand the contribution that describing practice through the use of a learning design can make to the design process. Findings from recent research is emerging (eg., Bennett et al, 2011; Kali, Goodyear \& Markauskaite, 2011) which will further understanding about how university teachers design.

\section{Conclusion}

This paper has reported the findings of a study that examined how academics used a visual learning design representation (LDVS) to document teaching practice and in so doing how it supported their design process. Eleven participants from across four Australian universities were interviewed about their experience in using the LDVS. This study showed evidence that the visual representation served as an aid to design because it provided a summary of pedagogical practice that could be easily understood. The relative simplicity of the representation, its adaptability and overall structure made the LDVS easy to use and enabled teachers to effectively communicate and share their ideas as well as reflect on their designs. Whilst it is important to continue to monitor the uptake of the LDVS as a learning design representation, future research should also focus on exploring how university teachers engage in design so as to better understand how documenting teaching practice via learning design representations can best support the design process.

\section{References}

Agostinho, S. (2009). Learning Design representations to document, model, and share teaching practice. In L. Lockyer, S. Bennett, S. Agostinho \& B. Harper (Eds.), Handbook of research of learning design and learning objects: Issues, applications, and technologies (pp. 1-19). Hershey, PA: Information Science Reference.

Agostinho, S., Harper, B., Oliver, R., Hedberg, J. \& Wills, S. (2008). A visual learning design representation to facilitate dissemination and reuse of innovative pedagogical strategies in university teaching. In L. Botturi \& T. Stubbs (Eds.), Handbook of visual languages for instructional design: Theories and practices (pp. 380-393). Hershey, PA: Information Science Reference. 
Bennett, S., Thomas, L., Agostinho, S., Lockyer, L., Jones, J. \& Harper, B. (2011). Understanding the design context for Australian university teachers: Implications for the future of learning design. Learning, Media and Technology, 36(2), 151-167. http: / / dx.doi.org/ 10.1080/17439884.2011.553622

Bennett, S., Agostinho, S. \& Lockyer, L. (2005). Reusable learning designs in university education. In T. C. Montgomerie \& J. R. Parker (Eds.), Proceedings of the IASTED International Conference on Education and Technology (ICET 2005) (pp. 102-106). Calgary, Alberta, Canada. http: / / www.actapress.com / Abstract.aspx?paperId=21223

Botturi, L. (2006). E²ML: A visual language for the design of instruction. Educational Technology, Research and Development, 54(3), 265-293. http: / / dx.doi.org/10.1007/ s11423-006-8807-x

Cooner, T. S. (2010). Creating opportunities for students in large cohorts to reflect in and on practice: Lessons learnt from a formative evaluation of students' experiences of a technologyenhanced blended learning design. British Journal of Educational Technology, 41(2), 271-286. http: / / dx.doi.org/10.1111/j.1467-8535.2009.00933.x

Conole, G. (2009). The role of mediating artefacts in learning design. In L. Lockyer, S. Bennett, S. Agostinho \& B. Harper (Eds.), Handbook of research of learning design and learning Objects: Issues, applications, and technologies (pp. 188-208). Hershey, PA: Information Science Reference.

Elliott, K., Boin, A., Irving, H., Johnson, E. \& Galea, V. (2010). Teaching scientific inquiry skills: A handbook for bioscience educators in Australian universities. [viewed 14 Jan 2011]. http: / / www.altc.edu.au / resource-teaching-scientific-inquiry-skills-melbourne-2010

Garzotto, F. \& Retalis, S. (2009). A critical perspective on design patterns for e-learning. In L. Lockyer, S. Bennett, S. Agostinho \& B. Harper (Eds.), Handbook of research of learning design and learning objects: Issues, applications, and technologies (pp. 113-143). Hershey, PA: Information Science Reference.

Falconer, I. (2007). Mediating between practitioner and developer communities: The learning activity design in education experience. ALT-J: Research in Learning Technology, 15(2), 155-170. http:// repository.alt.ac.uk/718/

Falconer, I., Finlay, J. \& Fincher, S. (2011). Representing practice: Practice models, patterns, bundles... Learning, Media and Technology, 36(2), 101-127. http: / / dx.doi.org/ 10.1080/17439884.2011.553620

Falconer, I. \& Littlejohn, A. (2006). Mod4L report: Case studies, exemplars and learning designs. [viewed 20 Feb 2007, verified 10 Sep 2011]. http: / / www.mod4l.com/tikidownload_file.php?fileId=2

Falconer, I., Beetham, H., Oliver, R., Lockyer, L. \& Littlejohn, A. (2007). Mod4L final report: Representing learning designs. http:/ / www.academy.gcal.ac.uk/mod4l/ [viewed 14 May 2007].

Frizell, S. S. \& Hübscher, R. (2009). Using design patterns to support e-learning design. In L. Lockyer, S. Bennett, S. Agostinho \& B. Harper (Eds.), Handbook of research of learning design and learning objects: Issues, applications, and technologies (pp. 144-166). Hershey, PA: Information Science Reference.

Gibbons, A. S. \& Brewer, E. K. (2005). Elementary principles of design languages and design notation systems for instructional design. In J. M. Spector, C. Ohrazda, A. Van Schaack \& D. A. Wiley (Eds.), Innovations in instructional technology: Essays in honor of M. David Merrill (pp. 111-130). Mahwah, NJ: Lawrence Erlbaum Associates. 
Goodyear, P. (2005). Educational design and networked learning: Patterns, pattern languages and design practice. Australasian Journal of Educational Technology, 21(1), 82-101. http:/ / www.ascilite.org.au/ajet/ajet21/goodyear.html

Hazelwood, P., Oddie, A. \& Barrett-Baxendale, M. (2009). Using IMS learning design in educational situations. In L. Lockyer, S. Bennett, S. Agostinho \& B. Harper (Eds.), Handbook of research of learning design and learning objects: Issues, applications, and technologies (pp. 282-294). Hershey, PA: Information Science Reference.

Herrington, J. \& Oliver, R. (2002). Description of online teaching and learning. (Edith Cowan University Online Unit IMM4141 in Graduate Certificate in Online Learning). [viewed 19 Sep 2006, verified 8 Sep 2011].

http:/ / www.learningdesigns.uow.edu.au/exemplars/info/LD20/

Hoban, G. (2009). Facilitating learner-generated animations with slowmation. In L. Lockyer, S. Bennett, S. Agostinho \& B. Harper (Eds.), Handbook of research of learning design and learning objects: Issues, applications, and technologies (pp. 312-329). Hershey, PA: Information Science Reference.

IMS Learning Design Best Practice and Implementation Guide Version 1.0 Final Specification (2003). IMS Global Learning Consortium Inc. http:/ / www.imsglobal.org/ [viewed 20 Jan 2004]

Jones, J., Bennett, S. \& Lockyer, L. (2011). Applying a learning design to the design of a university unit: A single case study. In T. Bastiaens \& M. Ebner (Eds.), Proceedings of World Conference on Educational Multimedia, Hypermedia and Telecommunications 2011 (pp. 3340-3349). Chesapeake, VA: AACE. http:// www.editlib.org/p/38334

Jones, J., Bennett, S. \& Lockyer, L. (2009). Investigating lecturers' use of learning designs to support technology enhanced course design. In T. Bastiaens et al. (Eds.), Proceedings of World Conference on E-Learning in Corporate, Government, Healthcare, and Higher Education 2009 (pp. 2719-2725). Chesapeake, VA: AACE. http:/ / www.editlib.org/p/32870

Kali, Y., Goodyear, P. \& Markauskaite, L. (2011). Researching design practices and design cognition: Contexts, experiences and pedagogical knowledge-in-pieces. Learning, Media and Technology, 36(2), 129-149. http:/ / dx.doi.org/10.1080/17439884.2011.553621

Kearney, M. (2011). A learning design for student-generated digital storytelling. Learning, Media and Technology, 36(2), 169-188. http: / / dx.doi.org/10.1080/17439884.2011.553623

Lockyer, L., Bennett, S., Agostinho, S. \& Harper, B. M. (Eds.) (2009). Handbook of research of learning design and learning objects: Issues, applications, and technologies. Hershey, PA: Information Science Reference.

Masterman, E. \& Manton, M. (2011). Teachers' perspectives on digital tools for pedagogic planning and design. Technology, Pedagogy and Education, 20(2), 227-246. http: / / dx.doi.org/10.1080/1475939X.2011.588414

McAndrew, P. \& Goodyear, P. (2007). Representing practitioner experiences through learning design and patterns. In H. Beetham \& R. Sharpe (Eds.), Rethinking pedagogy for a digital age: Designing and delivering e-learning (pp. 92-102). Oxon: Routledge.

McLaughlan, R. \& Kirkpatrick, D. (2009). Online role-based learning designs for teaching complex decision making. In L. Lockyer, S. Bennett, S. Agostinho \& B. Harper (Eds.), Handbook of research of learning design and learning objects: Issues, applications, and technologies (pp. 295-311). Hershey, PA: Information Science Reference. 
Neumann, S., Oberhuemer, P. \& Derntl, M. (2009). Visualizing learning designs using IMS learning design: The position of the graphical learning modeller. Proceedings of Ninth IEEE International Conference on Advanced Learning Technologies (pp. 732-733). http: / / dx.doi.org/10.1109/ICALT.2009.172

Oliver, R. \& Herrington, J. (2001). Teaching and learning online: A beginner's guide to e-learning and e-teaching in higher education. Edith Cowan University: Western Australia. http: / / elrond.scam.ecu.edu.au/oliver/2002/TALO2.pdf

Oliver, R. \& Littlejohn, A. (2006). Discovering and describing accessible and reusable practitioner-focused learning. In G. Minshull \& J. Mole (Eds.), The proceedings of Theme 1 of the JISC Online Conference: Innovating e-Learning 2006 (pp. 30-33). [viewed 25 Jan 2007]. http://www.jisc.ac.uk/media/documents/programmes/elearningpedagogy/ebook_theme1_a4.pdf

Sharpe, R., Beetham, H. \& Ravenscroft, A. (2004). Active artefacts: Representing our knowledge of learning and teaching. Educational Developments, 5(2), 16-21.

http:/ / www.seda.ac.uk/resources / files/publications_27_Educational\%20Dev\%205\%202.pdf

Seo, K. K. \& Gibbons, A. S. (2003). Design languages: A powerful medium for communicating. Educational Technology, 43(6), 43-46.

Smith, L. M. (1978). An evolving logic of participant observation, educational ethnography, and other case studies. Review of Research in Education, 6(1), 316-377.

http: / / dx.doi.org/10.3102/0091732X006001316

Voigt, C. (2010). A pattern in the making: The contextual analysis of electronic case-based learning. In P. Goodyear \& S. Retalis (Eds.), Technology-enhanced learning: Design patterns and pattern languages (pp. 107-122). Rotterdam: Sense Publishers.

Waters, S. H. \& Gibbons, A. S. (2004). Design languages, notation systems, and instructional technology: A case study. Educational Technology, Research and Development, 52(2), 57-68. http: / / dx.doi.org/10.1007/BF02504839

Author: Dr Shirley Agostinho

Faculty of Education, Interdisciplinary Educational Research Institute

University of Wollongong, NSW 2522, Australia

Email: shirleya@uow.edu.au

Shirley Agostinho is a Senior Lecturer in educational technology in the Faculty of Education at the University of Wollongong. Shirley's research interest in learning design spans ten years. She was a project manager and researcher for an Australian nationally funded project that focused on producing innovative reusable learning designs. She completed a Post-Doctoral Fellowship that examined how learning objects could be integrated with learning designs when developing online learning environments. She is currently involved in a number of projects investigating how the learning design concept could be used as a support tool for teachers.

Please cite as: Agostinho, S. (2011). The use of a visual learning design representation to support the design process of teaching in higher education. Australasian Journal of Educational Technology, 27(6), 961-978.

http: / / www.ascilite.org.au/ajet/ajet27/agostinho.html 